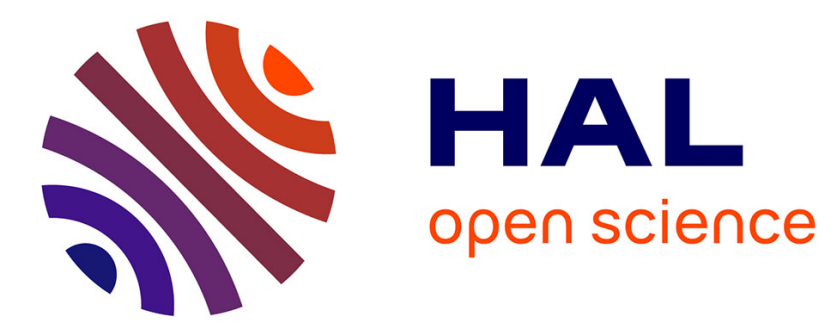

\title{
Ronald H. Coase and the Economics of Network Infrastructures
}

Claude Ménard

\section{To cite this version:}

Claude Ménard. Ronald H. Coase and the Economics of Network Infrastructures. Claude Ménard, Elodie Bertrand. The Elgar Companion to Ronald H. Coase, Edward Elgar Pub., 2016, 978-1-78254798-3. hal-01320425

\section{HAL Id: hal-01320425 \\ https://hal.science/hal-01320425}

Submitted on 23 May 2016

HAL is a multi-disciplinary open access archive for the deposit and dissemination of scientific research documents, whether they are published or not. The documents may come from teaching and research institutions in France or abroad, or from public or private research centers.
L'archive ouverte pluridisciplinaire HAL, est destinée au dépôt et à la diffusion de documents scientifiques de niveau recherche, publiés ou non, émanant des établissements d'enseignement et de recherche français ou étrangers, des laboratoires publics ou privés. 
Claude Menard

University of Paris (Pantheon-Sorbonne)

Ronald H. Coase and the Economics of Network Infrastructures.

In:

Claude Menard and Elodie Bertrand (eds)

\section{THE ELGAR COMPANION TO RONALD H. COASE}

Edward Elgar Pub., Cheltenham (UK), 2016

Chapter 14, Pages 187-203 


\section{Ronald H. Coase and the Economics of Network Infrastructures.}

\section{Claude Ménard ${ }^{1}$}

\section{Introduction.}

The legitimate emphasis put on the two leading contributions from Ronald Coase, 'The nature of the Firm' and 'The problem of social cost', has its dark side: it has kept under the bushel the rich empirical investigations that provided the scaffolding of most Coasean analyses. With the possible exception of his often revisited assessment of the Federal Communications Commission (1959) $)^{2}$ and his economics of the lighthouses (1974), very little attention has been paid to the continuing investment that Coase made in the analysis of network infrastructures. ${ }^{3}$ Throughout his long intellectual life, Coase published over 30 notes, papers, books, and extensive reports on what we now identify as network infrastructures, mainly telecommunications and postal services, but also gas, electricity, or 'public' transportation. ${ }^{4}$ He started doing so very early, in a devastating review of a book on the institutional structure of public utilities (1938a) and continued to do so without major disruptions until his very last contributions.

In this chapter, I propose an exploration of this abundant and rich material, with an emphasis on two major lessons: (1) the analyses developed by Coase remain particularly relevant for the modern analysis of network infrastructures; (2) they highlight an approach to regulation and policy a good deal more subtle than is often assumed. The chapter is organized as follows. Section 2 takes advantage of the detailed analyses that Coase made of the broadcasting industry to formalize the three levels that structure network industries. Section 3 examines Coase's investigation of the political economy involved in ruling network infrastructures and the so-called 'public utilities'. Section 4 discusses Coase's controversial 
views on the regulation of network industries and, more generally, on the mechanisms through which general rules are translated into specific ones. Section 5 provides some insight on how the actors operating within these rules adapt to the distortions thus introduced. Section 6 concludes by pointing out the role of technology as the backstage to Coasean analyses.

\section{Levels of investigation}

Let me start with reporting the different levels that shape the Coasean investigations into the 'institutional structure of production', levels that we can derive from the detailed study that Coase did seventy years ago (1947) about how the British Broadcasting Corporation (BBC) was born.

Wireless telephone, as the emerging radio broadcasting was called at the time, fell in Great Britain under the Wireless Telegraphy Act of 1904, which considered radio transmission as a means for sending messages in situations in which wire telephone was not available (typically ships). To make a long story short, Marconi Company started emitting in Great Britain on a very modest scale in the early 1920s, and needed a license to expand an activity that remained largely experimental. The existing regulation, monitored by the British Post Office, was not adapted to this new use of the emerging technology, which would allow transmitting news, commentaries, concerts, and so on. Marconi and other companies pressured the Post Office to allow extended broadcasting. Actually, these companies were not interested in broadcasting per se, but in creatg a demand for their receiving sets. After two years of arduous negotiations among the interested firms, and between the firms and the Post Office who pushed them to co-operate, the BBC was created as an actual monopoly for broadcasting activities, with its capital in the hands of the firms and under tight regulation (for example, all components of receiving sets had to be produced in Great Britain) implemented and monitored by the British Post Office. ${ }^{5}$ 
Through the detailed description provided in Coase paper, we can clearly identify the three levels that investigating the case should take into account: the institutional rules (the 1904 law) framing the game among the different players; a 'meso-institution' (the Post Office $)^{6}$, which interprets, adapts, implements and monitors in its own way the rules of the game defined by the law; and an organizational arrangement (the BBC, pooling firms that remained competitors) that became responsible for delivering the specific service (broadcasting) and for organizing transactions with operators accordingly. These are the three dimensions on which I focus in the coming pages. There is another dimension that provides an essential background to Coase's story: the technological changes in broadcasting that imposed adjustment of the rules of the game and adaptation of parties involved in the usage of this new technology. However, in the coming pages I shall focus on the institutional dimension with its three levels. The following figure summarizes these interactions.

Figure 14.1: Interactions defining the institutional structure of production.

[INSERT FIGURE 14.1 HERE]

\section{The political economy of formal institutions}

In his analysis of network infrastructures, Coase consistently referred to laws and other formal rules that frame the modalities for the delivery of goods and services at stake, but also create room for interpretation and adaptation that open the way to political interference. As he clearly stated: "Economic regulation is the establishment of the legal framework within which economic activity is carried out." (1977: 5). This framework results from legislative action but also from judiciary interpretation. For example, the development of broadcasting in the UK fell under the Wireless Telegraphy Act from 1904, which transferred jurisdiction on new 
means of communication to the Post Office and evolved through a mix of political interference, positions defended by the General Postmaster, and interpretations by Courts (1947). Similar observations can be made regarding the nationalization of electricity (1950), the development of postal services (1961), or the evolution of the jurisdiction over the lighthouses services (1974).

\section{Motivations to political intervention}

One important aspect exhibited by Coase is the fluctuation in the arguments supporting political interferences at different points in time. This is well illustrated by the changing positions endorsed by the British Conservatives before and after the general election of 1951 regarding the monopoly of the BBC over TV broadcasting (1954: 217 sq.).

Variation in the arguments developed by policy makers to motivate regulation and their adaptability to circumstances is striking. It goes from strategic considerations, as illustrated by the royal proclamations of 1591 and 1606 creating a monopoly over postal services “... with a view at discouraging, discovering and suppressing treason and sedition" (1955: 25) or by the nationalization of electricity in 1948 (1950: 9-10), to issues of coordination that would be imposed by new technologies, for example the need in the case of electricity (1950) to merge undertakings that were much too small and often involved local authorities or small firms with overlapping jurisdiction, or the delivery of express mail (1955; 1961). Other arguments, although less often developed by policy makers, are about fairness to consumers, which motivated the adoption of the 'penny stamp' for all letters delivered over the national territory (1939); regional development, as a justification to the nationalization of electricity (1950); or the capacity of the government to create incentives for innovation, as would be the case for broadcasting $(1947 ; 1954)$ or electricity (1950).

There are also less explicit factors often motivating policy makers. There are considerations about employment or price control, notwithstanding the awareness of some 
parties to the debate that it goes against economic efficiency (1950: 14; 1961: 60 sq.). And behind all these arguments, there is often the action of lobbies, which can play in both directions: limiting the incentive to extend monopoly, as when Oxford University successfully resisted the Post Office in maintaining a semi-private postal system in the 1880s (1955: 3335) or when private firms lobbied to impose the innovative technologies of radio broadcasting in the 1920 's or TV in the 1930's; or pushing towards more regulation so as to provide support to monopoly power, as illustrated by the continuing efforts to control or even prohibit the payola system in the music industry (1979) from the 1930s to the 1950s, when the top majors (Capitol, Columbia, Decca, and RCA) opposed payola apparently because it mostly benefited the newcomers diffusing 'junk music' (Rock \& Roll, Rhythm and Blues)! ${ }^{7}$

This variation in arguments already made the impulse to regulate suspicious to Coase. His reservations increased over time when looking at the impact of political interferences through legislation.

\section{Impact of political interference}

Coase pointed out repeatedly three major impacts of extensive regulation by policy makers, with potentially devastating effects on the running of a market economy. ${ }^{8}$

First, political interference introduces distortions in the price system. Early on, in his discussion of the nationalization of electricity (1950) or the establishment of universal postal services with monopolistic privileges (1955), Coase noted that the apparently well-intentioned decision to have receipts covering costs for an entire system can easily slip into extended cross-subsidies, making the system totally opaque. Another problem comes from the "doctrine of uniformity" of prices over the whole territory, as initiated by the "penny system" adopted in the UK in 1840 and that provided much justification to support the monopoly of the Post Office, a system that introduced cross-subsidies among regions, distorting the costs supported by users. More generally, Coase argued that this danger can pop out of all measures intending 
to standardize an industry, as illustrated by the progressive transfer of lighthouses from private interests to public authorities (1974: 368). Another form of discrimination that is tempting for policy makers regulating network infrastructures is to develop opaque structures of privileged rates benefiting specific categories of consumers, as commonly practiced in the electricity or railroad industries (1950).

Second, and this aspect increasingly worried Coase, there is the risk of political interference on the content of services delivered by network infrastructures submitted to regulatory supervision. This was so at the very beginning of the regulated postal services, with the Royal Proclamation of 1591 allowing the government to open letters to limit risks of treason and sedition, a right confirmed as lately as in the revision of the status of the Post Office in the 1950s (1955: 25). But, according to Coase it is the regulation of broadcasting that made this risk even more obvious. As early as 1954, he noticed contradictions among policy-makers, in this case led by Conservatives, about the impact of the monopoly of the BBC on TV broadcasting: on the one hand it was considered that the monopoly could be justified, considering the "excellent and reputable broadcasting service for which this country is renowned" (White Paper from 1952, quoted in 1954: 218), on the other hand it was also emphasized that competition could allow more diversified opinion and improved the quality of programs (White Paper from 1953). The issue of the quality of programming and the capacity of regulators to guarantee quality ${ }^{9}$ became an important part of the debate in Great Britain as well as in the US about the role of advertising in financing programs (1954: 216; 1977). And it was also this problem of control by the FCC over the content, with respect to the provision of "good music" as opposed to "this so-called junk music, rock-and-roll stuff" (quoted in 1979: 293), which fed the debate on payola.

Last, laws and regulations can have a direct impact on the organization of the industry or even on the internal organization of a firm. This issue is central in Coase famous 'Proposal' 
about the tasks of industrial organization (1972), but it can be found in earlier papers. For example, in his analysis of the nationalization of electricity Coase (1950) noted that political interference had already structured part of the industry through the British Central Electricity Board created in 1926, a movement amplified by the nationalization of 1948, with a Ministry supervising the British Electric Authority in charge of the production of electricity, this Authority having supervisory power over the Area Boards in charge of distribution, so that an entire chain of command-and-control organized the industry. Legislative and regulatory measures can also interfere with the internal organization of firms, as well illustrated by the pressure from the Post Office, operating as a regulator, in structuring the $\mathrm{BBC}$, imposing an alliance between rival companies and the allocation of shares among parties to the initial arrangement (1947).

\section{Intermediate devices: translating general rules into specific ones}

Understanding the relationship between general rules and specific ones and the devices through which the general rules are actually implemented is a task to which Coase devoted a substantial part of his academic life. Three regulatory devices that fall under what I call 'meso-institutions' have been identified by Coase, although his attention increasingly focused on one of them, namely: regulatory agencies.

\section{Self-Regulation}

One possibility is for a pool of otherwise competing firms to organize and regulate the market. This was the solution prepared by the British Post Office to organize the new market of radio broadcasting in the 1920s (1947). Responsible for implementing the general rules defined in the Wireless Telegraphy Act, the General Postmaster who initially considered regulating directly the emerging industry of radio broadcasting finally adopted a different 
solution, pushing rival entities led by companies making receivers to create a pool that would control broadcasting. The Post Office pampered an agreement, signed in 1922, according to which the initial six members would equally share the capital of the new entity, the BBC, with a monopoly over radio broadcasting submitted to restrictions, for example the possibility for newcomers to join the club thus reducing the number of shares of the initial shareholders, all of this under the supervision ... of the Post Office. So it was that the BBC was initially a private entity in charge of monitoring the network under the umbrella and guidance of a public entity.

\section{Provider as regulator}

A second option is to make a public utility directly in charge of regulating the sector. One example is provided by the British Post Office, ${ }^{10}$ confronted by the emergence of "messenger companies' which, already in the 1860 s, wanted to take advantage of loopholes in the law from 1840 to circumvent the monopoly of the Post Office and develop their own delivery services. Initiatives came from private entrepreneurs, but also from universities (Cambridge and Oxford). As reviewed with a profusion of details by Coase $(1955 ; 1962)$, the Post Office fluctuated in deciding how to implement the law, for example between developing in-house the express delivery service so as to confirm its monopoly, or 'delegating' the provision of these services through concessions with royalties paid to the Treasury, with the additional difficulty of determining the basis for these royalties (number of letters? their weight? the net receipt from the companies?). Another example is the provision of lighthouses (1974), which evolved from private initiatives that developed rapidly in the $18^{\text {th }}$ century, to the centralization in the hands of one private entity (namely the Trinity House, which obtained a form of monopoly over lighthouses in a 1836 Act of the British Parliament) to more direct control by public authorities at the end of the $19^{\text {th }}$ century. ${ }^{11}$

\section{Regulatory Agency}


The third possibility, which prevailed (and still does) at the time Coase developed his analyses, is that of government agencies, with what became the canonical Coasean example, the Federal Communications Commission.

A major step towards subtracting the regulation of broadcasting from the direct control of policy-makers and delegating it to a relatively autonomous agency was made in the US with the creation in 1927 of the Federal Radio Commission, transformed in 1934 into the Federal Communications Commission to extend the jurisdiction of the agency to telephone, telegraph and a newcomer, television. Scrutinizing the agency and the progressive extension of its power, Coase (1959) pointed out three issues that he viewed as challenges relevant for all other regulatory agencies. First, the control over the allocation of rights to use a scarce resource, in this case wavelength, through administrative procedures rather than through the price mechanism, motivated by a single technological argument, the risk of interferences. Second, the extremely high risk in delegating control to a bureau, which is what an agency is, that a technically motivated allocation of rights be extended over the conduct of beneficiaries and, progressively, over the content in their usage of these rights, for example by interfering with programs (1959: 38). Last, there is the possibility that a regulatory agency control the action and development of the industry by regulating its mode of financing, as illustrated by the debate about the role of sponsoring and advertising $(1959 ; 1965 ; 1979$; also Pratten, 2001).

\section{To sum up}

Two important lessons can be drawn from the Coasian analysis of regulation. First, Coase pioneered the need to take into account the role of intermediate arrangements when examining the costs and benefits of regulation. Laws and decrees do not operate into a world of benevolent and neutral actors, they need being implemented through intermediary devices, 'meso-institutions', that develop their own agenda and their own interpretation of the 
institutional rules of the game. Second, and this view is symmetrical to the Coasean analysis of the organization of transactions, there are different ways to do so. Among the three arrangements that he identified, Coase increasingly focused on regulatory agencies, likely because of their growing role in the economy, particularly in the US. He also became more and more suspicious of their expected benefits. Nevertheless, he continuously pointed out the need to assess these alternative 'meso-institutions' comparatively, taking into account other solutions (for example, using the price mechanism) and estimating the costs involved (1959:18-19). In that respect, his position regarding the institutions of regulation was consistent with his approach to organizational arrangements.

\section{Adopting and adapting: market structures and the firms}

There is a paradox when it comes to the analysis of the third level in the framework I derived from Coase, the level at which network infrastructures actually deliver goods and services. On the one hand, Coase continuously pointed out the need for economists to carefully examine each industry in its specificity (1972) and, within an industry, how organizations are structured and their decisions framed and implemented, an issue he strongly emphasized in his 'Nobel lecture' (1992: 714).

On the other hand, Coase never systematically developed his views or substantiated his intuition with respect to this dimension. Nevertheless he provided useful insights for future research, opening the way to Williamson and those involved in that branch of the new institutional agenda.

\section{From integration to monopolies}

In line with his famous article from 1937, which pointed out the existence of "alternative methods of coordinating production" (1937: 389), Coase viewed the role of the government in 
public monopolies over network infrastructures as that of an "entrepreneur-coordinator" (1937: 388) and considered the possible arrangements when substituting public ownership or tightly supervised private entities to the price mechanism.

Right after the publication of 'The Nature of the Firm,' Coase reviewed two books: one book reported on the exercise of public ownership at the $\mathrm{BBC}$, the Central Electricity Board, and the London Passengers Transport Board, and that concluded about "the suitability to its own purposes of this form of public ownership and control," a view that Coase firmly challenged (1938a: 485). The other book was about the British Gas Industry, in which the author maintained that "putting the control of tariffs in the hands of Gas Commissioners" could be an efficient way to allocate resources, a conclusion with which the young Coase deeply disagreed (1938b: 727). These contributions were complemented by a third paper in which Coase discussed the adoption of a uniform price system that largely contributed to the consolidation of the monopoly of the British Post Office, and that "led to similar action on the part of foreign Governments ... and the demand for uniform charges over the country for, for example, the telephone and electricity."(1939: 424). Thus, a research program was born that would occupy Coase all his life. ${ }^{12}$

Of particular concern for Coase was the propensity towards the monopolistic structuration of network infrastructures. Let me emphasize two aspects of the complex developments he devoted to this 'institutional structure of production'. ${ }^{13}$ First, Coase became aware that various organizational arrangements can support a monopolistic position, as illustrated by his analysis of the BBC (1947), the postal services (1955), the lighthouses (1974), and so on. A monopoly can be formally established by the law, as with the Post Office Reform of 1840, or can develop de facto, as with the case of the BBC that did not get legal monopoly, at least in the initial stage (the Post Office had the right to license other broadcasting companies), but obtained tight control over the industry in making an obligation 
to new entrants to use patents (mainly on receivers at that time) held by the pool of companies that formed the BBC (1947: 205). ${ }^{14}$ Second, Coase showed through several examples, particularly in his analysis of the policy of the British Post Office $(1955 ; 1962)$ or his historical review of lighthouse provision (1974), the strong propensity of monopolies initially established for specific activities to extend their jurisdiction, particularly through a strategy oriented towards "narrowing exceptions" (1955:28). Activities initially considered as ancillary and that could easily be delegated to private entrepreneurs end up consolidating the monopoly, without consideration for efficiency, as illustrated with the case of 'express delivery' in postal services (1961).

\section{The internal structure of firms under public control}

Another issue to which Coase referred repeatedly and that he summarized in his "Proposal" (1972) concerns the impact of regulation on the internal structure of the monopolies thus established or, more generally, on the organization and strategy of regulated firms. Here again, many examples can be found in several papers, for example regarding the organization and jurisdiction of the BBC (1947), although none got into the details of internal organizations, notwithstanding calls to do so.

One possible exception is the analysis of 'the nationalization of electricity in Great Britain' (1950). In this paper, Coase carefully examined the allocation of decision rights between the Ministry, responsible for the general policy regarding energy; the British Electric Authority, responsible for the generation of electricity; the Area Boards in charge of distribution; and the Consultative Councils attached to each Area Board to represent users' interests. Behind its complexity, the structure remains highly hierarchical, the Ministry defining policies ('after consultation') and appointing members of all bodies, and the BEA tightly supervising the Area Boards, particularly when it comes to tariffs, revenues, and expenditures (1950: 8-9). The official goals of this arrangement (keeping control over the 
strategic provision of energy; organizing regional development; and providing incentives for research) should not obscure the underlying rationale (regulating employment... and prices), pushing firms under public control to adapt to political interference. Such example closes the loop of interactions among the three levels identified in our framework.

Notwithstanding this exception and a few others $(1947,1974, \ldots)$, Coase did not develop the analysis of the internal structure of firms nor provided tools to go further in this direction, as he acknowledged in 1972 as well as in his Nobel Lecture, in which he paid homage to Williamson for having made important steps in this direction (1992: 718).

\section{In the end: Property rights at stake}

What primarily underlies the Coasean analysis of the institutional structure of network infrastructures and of their regulation is the central issue of the delineation and allocation of property rights. As pointed out by Allen and Barzel, ${ }^{15}$ the relationship between property rights and transaction costs is at the core of Coase research program.

Let me focus on a few illustrations. In his early contribution on "British Experiments in Public Ownership and Control" (1938a), Coase already pointed out the risk of "monopolistic vested interest" resulting from the allocation of rights to three publicly controlled companies (the Central Electricity Board, the BBC, the London Passenger Transport Board); the neglect of the costs of standardization (to which he will later refer as the "doctrine of uniformity"), an important argument for those favorable to public ownership; and the danger of public corporations becoming independent from the Parliament, thus putting on a shelf the potential conflicts between producer and consumer interests. In sum, as early as 1938, Coase questioned "the suitability to its own purposes of this form of public ownership and control" (quoted in 1938b: 485) and the efficiency of these institutional arrangements.

Coase came back repeatedly to this issue of the allocation of rights and its impact throughout all his academic career, from his analysis of the origin and role of the BBC (1947: 202 sq.) to 
his famous examination of the 'allocation of frequencies" in his FCC paper (1959: 17 sq.) or his "proposal for research" in industrial organization (1972: 69 sq.), all the way to the last chapter of his last book (Coase and Wang, 2012: chap. 6), not to mention, of course, the entire "Problem of Social Cost" (1960).

Confronted by the expanding role of public agencies in the period in which he developed his analyses, Coase became increasingly opinionated, adopting a systematically suspicious attitude towards public intervention and pointing out the risk of neglecting solutions in which the price mechanism could play its role. This critical position came out of his growing conviction that political interference translated in misallocation of rights, as in broadcasting frequencies, and high transaction costs that penalize users of network infrastructures. However, Coase simultaneously maintained the need to assess comparatively the costs and benefits of various institutional allocations of property rights, their impact on transactions and on the efficiency of their organization. As firmly stated in the conclusion of "The Problem of Social Cost":

"Furthermore, we have to take into account the costs involved in operating the various social arrangements (whether it be the working of market or of a governmental department) as well as the costs involved in moving to a new system. In devising and choosing among social arrangements we should have regard for the total effect. This, above all, is the change in approach which I am advocating." (1960: 44).

This message remains entirely relevant nowadays.

\section{Conclusion}

In this paper I have explored the three levels of analysis that we can clearly identify in Coase early examination of network infrastructures, and I have paid special attention to the 
intermediate level, the level of "meso-institutions", to which Coase devoted an increasing part of his efforts through his analysis of regulation and the role of regulatory agencies. In doing so, I have neglected other important aspects of his investigation in the economics of infrastructure, for example the need to analyze the pricing mechanism at work in public utilities (explicitly developed in 1970b, but already present in 1946); or the need to take into account the way property rights are delineated and allocated. ${ }^{16}$

However, there is one issue I did not develop that is systematically neglected by Coase readers, and that I found of particular importance for understanding his analyses: it is the role of technology as the unavoidable background to any relevant exploration of network infrastructures. In his fundamental paper on the origin of the BBC (1947), Coase already emphasized the misperception of the emerging technology of radio broadcasting, initially viewed as a wireless telephone that would compete with telegraph. This misperception fed the command-and-control strategy adopted by the British Post Office but also the strategies of private companies that pushed to get rights to broadcast less by an inherent interest to do so than by their expectation to benefit from another technology, the development of receivers. In sum, the Post Office was concerned with the software, while the companies focused on the hardware. The BBC came out as a compromise between these different perceptions of the new technologies. Similarly, examining how institutions monitored the emerging television in the late 1920s - early 1930s, Coase (1954) insisted on the perception of this new technology in shaping the industry, with the BBC initially uninterested and later wanting to capture what came to be viewed as the 'natural extension' of radio broadcasting, and private firms initially mostly interested in keeping control over programs as source of revenues while using the BBC as a broadcaster. Other examples could be developed (for example, about the allocation of rights over high frequency waves, explored by Coase, 1970). 
Technical systems and their characteristics thus provided background to Coase analyses, making the allocation of rights over a new technology an important piece of his framework, with the underlying dynamics of innovation resulting in tensions between private initiatives and public monopolies or regulation. Also noticeable is how Coase understood the importance of the underexplored links between technological innovation and organizational innovation, as illustrated by his analysis of broadcasting or of messenger companies.

There are of course issues that escape the attention of Coase and/or on which he adopted ambiguous or controversial positions. For example, coming back to the role of the FCC, he argued that "No significant improvement in the present situation is to be expected unless the financial basis of the industry is changed" (1965: 166). He added that:

"The FCC, by its emphasis on the financial qualification of the claimants, must inevitably tend to favor firms or individuals who are already financially well-endowed. The FCC is, in fact, engaged in an anti-poverty campaign for millionaires ... All this would change if the FCC sold its grants to the highest bidders." (1965: 165).

However, it is not clear how the auctions that he favored would improve quality and better take on board the interests of less well-endowed individuals or groups; nor is it obvious how the pay-television system that he supported as opposed to the sponsor system would automatically improve quality through a better match between outputs and consumers' preferences (Pratten, 2001). Another example of a controversial issue concerns the role of courts. Coase increasingly opposed regulation of network infrastructures through agencies and rather favored regulation through the legal system, viewed as more respectful of rights. But he also came to confess (1977) that Courts is the most regulated market for ideas, and a market that involves high transaction costs.

Confronted to controversial views or hesitations with respect to crucial policy issues regarding network infrastructures, we know what Coase's answer would have been. First, 
proceed through comparative assessment. After having criticized the role of regulation, he concluded: "But this does not mean that we would be better off if all regulations were abandoned." (1977: 8). Second, stick to the facts and the challenges they raise.

“An inspired theoretician might do as well without empirical work, but my own feeling is that the inspiration is more likely to come through the stimulus provided by patterns, puzzles, and anomalies revealed by systematic data-gathering, particularly when the prime need is to break our existing habits of thought." (1972: 71)

\section{REFERENCES}

Bertrand, E. (2010), "The three roles of the 'Coase theorem' in Coase's works", The European Journal of History of Economic Thought, 17(4), 975-1000.

Campbell, D. and M. Klaes (2005) 'The principle of institutional direction: Coase's regulatory critique of Intervention'. Cambridge Journal of Economics, 29: 263-288

Coase, Ronald H. (1937) “The Nature of the Firm”, Economica. 4 (16): 386- 405

- $\quad$ (1938 a) "British Experiments in Public Ownership and Control by Terence H.

O'Brien.” Economica, 5 ( 20): 485-487

- (1938b) “The British Gas Industry: An Economic Study by Philip Chantler.” The Economic Journal, 48 (192): 727-728

- (1939) “ Rowland Hill and the Penny Post”, Economica, 6 (24): 423-435

(1947) “The Origin of the Monopoly of Broadcasting in Great Britain”,Economica, 14

(55): $189-210$

(1948) “Wire Broadcasting in Great Britain”, Economica , 15 (59): 194-220

(1950) “The Nationalization of Electricity Supply in Great Britain.” Land Economics $26(1): 1-16$ 
- (1954) “The Development of the British Television Service”, Land Economics 30 (3): 207-222

(1955) “The Postal Monopoly in Great Britain: An Historical Survey”, in J.K. Eastham (ed.) Economic Essays in Commemoration of the Dundee School of Economics, 1931-55. W. Culross, Dundee School of Economics, Dundee. 25-37

- (1959) “The Federal Communications Commission”, Journal of Law and Economics 2 (October): 1-40

- (1960) “The Problem of Social Cost”, Journal of Law and Economics, 3 (October): 144

(1961) “The British Post Office and the Messenger Companies”, 4 Journal of Law and Economics 12-65

(1962) “The British Post Office and the Messenger Companies”, Journal of Law and Economics, 4 (October): 12-65

(1965) "Evaluation of Public Policy Relating to Radio and Television Broadcasting: Social and Economic Issues”, Land Economics 41 (2): 161-168 (1970) “The Theory of Public Utility Pricing and its Application", 1 Bell Journal of Economics, 1 (1): 113- 128..

- (1972) “Industrial Organization: A Proposal for Research”, in Victor R. Fuchs (ed.) Policy Issues and Research Opportunities in Industrial Organizations, Cambridge (MA): National Bureau of Economic Research.

- $\quad$ (1974) “The Lighthouse in Economics”, Journal of Law and Economics 17 (2): 357376.

- (1977) “Advertising and Free Speech”, Journal of Legal Studies, 6 (1): 1-34 (1979) "Payola in Radio and Television Broadcasting", Journal of Law and Economics 22 (2): 269-328 
- (1992) “The Institutional Structure of Production: The 1991 Alfred Nobel Memorial

Prize Lecture in Economic Sciences". American Economic Review 82 (4): 713-719

Coase, Ronald H. and Ning Wang (2012) How China Became Capitalist. New York:

Palgrave Macmillan

Medema, S. G. (1994). Ronald H. Coase, London, MacMillan.

Ménard, Claude (2014) "Embedding Organizational Arrangements: Towards a General Model." Journal of Institutional Economics 10 (4): 567-589

Pratten, Stephen (2001) “Coase on broadcasting, advertising and policy”, Cambridge Journal of Economics, 25: 617-638

\section{NOTES}

\footnotetext{
${ }^{1}$ I am very grateful to two anonymous referees and Elodie Bertrand for their comments and suggestions.
}

${ }^{2}$ Without other precision, dates in parenthesis refer to contributions from Coase listed at the end of this chapter.

${ }^{3}$ An important exception is Pratten (2001), who explored Coase's contributions to the analysis of broadcasting. See also Medema (1994: chap. 5) for an assessment of Coase's empirical studies.

${ }^{4}$ Hereafter we refer to 'network infrastructures' in a broader sense than the frequent usage associated to computer systems.

${ }^{5}$ The rules and allocation of rights framing the creation of the BBC can be found in 1947: 202 sq.

${ }^{6}$ In a nutshell, meso-institutions are subsidiary arrangements operating under general rules (laws, customs) and defining, delineating, translating these general rules into specific ones 
(sectoral and/or regional), thus framing actual transactions. Regulatory agencies are illustrative. For a discussion of the concept, see Ménard (2014).

${ }^{7}$ The payola system is the practice already implemented in the 1920 s by publishers of music and producers of programs to pay musicians and/or programmers to give priority to the diffusion of specific songs or programs.

${ }^{8}$ Coase's political positions with respect to public intervention are complex and far more subtle than often viewed. For a subtle analysis of Coase's positions on regulation and intervention from 1937 to 1961, see Campbell and Klaes (2005). See also Bertrand's discussion of the role of the 'Coase Theorem' in the debate about public policies (Bertrand, 2010).

${ }^{9}$ The British White Paper from 1953 on broadcasting referred to measures needed to ensure "adequate standards of taste" (1954: 221).

${ }^{10}$ Beside its economic significance, the interest of Coase for the Post Office likely came out of the fact that his parents were its employees.

${ }^{11}$ See Bertrand's chapter in this volume.

${ }^{12}$ Interestingly, an 'accidental' event likely played a key role in this orientation: Coase got involved in the analysis of public utilities when he had to replace Hicks and deliver a course on this topic in 1935.

${ }^{13}$ Other aspects are developed in several chapters of this book.

14 "It is broadly true to say that the establishment of the broadcasting service in Great Britain as a monopoly was the result of Post Office policy." (1947: 205).

${ }^{15}$ Chapter 6. See also Arrunada's and Drobak's chapters in this volume.

${ }^{16}$ Several chapters of this book are dealing with these problems. 